\title{
Emerging Role of Exosomes in Retinal Diseases
}

\author{
Zhengyu Zhang, Aime Mugisha, Silvia Fransisca, Qinghuai Liu, Ping Xie* and \\ Zizhong Hu*
}

Department of Ophthalmology, The First Affiliated Hospital of Nanjing Medical University, Nanjing, China

\section{OPEN ACCESS}

Edited by:

Sirio Dupont,

University of Padua, Italy

Reviewed by:

Jeffrey Sundstrom,

Penn State Milton S. Hershey Medical

Center, United States

Nora Beatriz Calcaterra,

Consejo Nacional de Investigaciones Cientificas y Técnicas (CONICET),

Argentina

${ }^{*}$ Correspondence:

Ping Xie

xieping9@126.com

Zizhong $\mathrm{Hu}$

huzizhong@njmu.edu.cn

Specialty section:

This article was submitted to

Signaling,

a section of the journal

Frontiers in Cell and Developmental

Biology

Received: 18 December 2020

Accepted: 05 March 2021

Published: 01 April 2021

Citation:

Zhang Z, Mugisha A, Fransisca S,

Liu Q, Xie P and Hu Z (2021)

Emerging Role of Exosomes in Retinal

Diseases.

Front. Cell Dev. Biol. 9:643680.

doi: 10.3389/fcell.2021.643680
Retinal diseases, the leading causes of vison loss and blindness, are associated with complicated pathogeneses such as angiogenesis, inflammation, immune regulation, fibrous proliferation, and neurodegeneration. The retina is a complex tissue, where the various resident cell types communicate between themselves and with cells from the blood and immune systems. Exosomes, which are bilayer membrane vesicles with diameters of 30-150 nm, carry a variety of proteins, lipids, and nucleic acids, and participate in cell-to-cell communication. Recently, the roles of exosomes in pathophysiological process and their therapeutic potential have been emerging. Here, we critically review the roles of exosomes as possible intracellular mediators and discuss the possibility of using exosomes as therapeutic agents in retinal diseases.

Keywords: exosome, extracellular vesicles, retina, stem cell, miRNAs

\section{INTRODUCTION}

Retina, is essential for performing the first stages of image processing. Multiple retinal diseases, such as age-related macular degeneration (AMD), diabetic retinopathy (DR), retinal detachment (RD), and glaucomatous neuropathy, involve angiogenic, neurodegenerative, inflammatory, and fibrotic changes which disrupt the normally transparent retina and cause irreversible vision loss (Flaxman et al., 2017). As part of central nervous system, the retina is composed of neurons, glias, endothelial cells, pericytes, immune cells, and extracellular matrix components (Figure 1). However, questions remain unveiled concerning which changes occur in these individual cells and how they interplay with each other in diseased retinal microenvironment. Deeper understanding of the cell-to-cell communication and molecular changes in retinal diseases is improvement for future preventative and therapeutic strategies.

Extracellular vesicles (EVs) are a general term for secretory vesicles, which can be classified as exosomes, microvesicles, or apoptotic bodies according to the size, surface proteins, and internal cargos. The exosome, usually ranging from 40 to $160 \mathrm{~nm}$ in diameter, originates from the inward budding of the plasma membrane (Figure 1) and plays an important role in intercellular communication via cargo molecules. Biogenetically, the extracellular components (such as RNAs, proteins, lipids, metabolites, small molecules) and the cell surface proteins sprout inward through the invagination of the plasma membrane, forming the early-sorting endosomes (ESEs). ESEs then gradually matured into late-sorting endosomes (LSEs), and transformed to multivesicular bodies (MVBs) through the inward invagination of the endosomal limiting membrane (Alenquer and Amorim, 2015; Gurunathan et al., 2019). If not fusion with lysosomes that degrade their cargo, the MVBs will be transported to the plasma membrane and released into extracellular environment as exosomes. The lipid bilayer of exosomes contains specific lipids such as cholesterol 
and phosphatidylserine, which protect the contents from degeneration (Figure 1; Alenquer and Amorim, 2015; Gurunathan et al., 2019). During the past decade, exosomes have attracted increasing attentions and emerged as a promising field of biomedical research for a range of diseases. First, exosomes have been suggested as biomarkers for diagnosing diseases (Howard et al., 2020; Xiao et al., 2020). Second, cargos within the exosomes participate in cell-to-cell communication through receptor-ligand interactions with target cells (Becker et al., 2016; van Niel et al., 2018). Third, exosomes, in the form of drug delivery vehicles, have the great potential to develop as therapeutic tools for a variety of currently incurable diseases (Xu R. et al., 2018; Liu and Su, 2019).

The exosomes, shed by various ocular cell type, can exist extensively in ocular fluid such as tears, aqueous humor, vitreous humor, and blood. Although the roles of various cell-derived exosomes have been increasingly investigated in diverse ophthalmic diseases, knowledge regarding the function of exosomes in retinal diseases remains limited. Here, we performed an extensive literature review to present the latest information regarding the separation strategies of exosomes, cargos loaded in exosomes, and more importantly, the role of exosomes in retinal diseases and their potential applications as therapeutic tools.

\section{CARGOS LOADED IN EXOSOMES}

\section{Mechanism of Cargos Loaded Into Exosomes}

Most of the reports concerning cargos loaded in exosomes have focused on the non-coding RNAs, including miRNA, lncRNA, and circRNA. To investigate the components in exosomes, the first step is to efficiently separate exosomes from biological fluids. Table 1 shows the details of the mostly used strategies at present. In 2007, Valadi et al. (2007) discovered the existence of mRNA and miRNA in exosomes for the first time, and found that exosomes can transport mRNA and miRNA to receptor cells. Subsequently, Goldie et al. (2014), found that the proportion of miRNA isolated from the exosome was higher than that of the parent cells, suggesting that the entry of miRNA into the exosome may have a special sorting mechanism. Based on previous studies, there are four possible pathways of sorting mechanism of miRNA into exosomes as (1) the neural sphingomyelinase 2 (nSMase2)dependent pathway (Guduric-Fuchs et al., 2012); (2) the miRNA motif and sumoylated heterogeneous nuclear ribonucleoproteins (hnRNPs)-dependent pathway (Villarroya-Beltri et al., 2013); (3) the 3 -end of the miRNA sequence-dependent pathway (Koppers-Lalic et al., 2014); and (4) the miRNA induced silencing complex (miRISC)-related pathway (Frank et al., 2010).

In the research of Qu et al. (2016), it was also found that sumoylated hnRNPA2B1 could specifically encapsulate LncARSR into exosomes. Li et al. (2015) speculated that the sorting mechanism of circRNA may be associated with the changes of related miRNA levels in production cells.

As for protein sorting, studies have shown that the endosomal sorting complex required for transport (ESCRT) family plays an important role in protein synthesis and sorting into exosomes
(Juan and Fürthauer, 2018). Meanwhile, other voices also proposed the protein sorting is independent of ESCRT family (de Gassart et al., 2003; Gangalum et al., 2011). de Gassart et al. (2003) highlighted that the presence of lipid microdomains in exosomal membranes participates in exosome formation and structure. When lipid rafts is destroyed, the secretion of exosome containing protein is then inhibited (de Gassart et al., 2003; Gangalum et al., 2011). These studies of cargos sorting mechanisms can provide strategies for disease treatment by intervening the process of cargos loaded into exosome s, or develop more efficient exosome-mimics as a novel tool for drug delivery.

\section{Cargos in Exosomes}

The role of exosomal nucleic acids, especially the ncRNA, has attracted more and more attentions. At present, the most extensive areas of research are mainly focused on three parts. First, exosomal ncRNA as diagnostic biomarkers for disease. Of note, exosomal ncRNA has the advantage as diagnostic biomarkers since exosomes exist in various types of human body fluids such as blood, urine, saliva, which can be easily obtained in clinic. For example, the upregulation of miRNA-139-3p in plasma exosome can predict the occurrence of colorectal cancer (Liu et al., 2020). In urine exosomes, the expression of miR-194$5 \mathrm{p}$ was significantly down-regulated in patients with autosomal dominant polycystic kidney disease (Magayr et al., 2020). In tear exosomes, the expression of miR-21 and miR-200 of patients with metastatic breast cancer was higher than that of healthy volunteers (Inubushi et al., 2020). Second, exosomal ncRNA participate in cell-to-cell communication through receptorligand interactions with target cells, promoting pathologic process such as inducing abnormal angiogenesis (Conigliaro et al., 2015), regulating immune response (Xu Z. et al., 2018), and enhancing chemical resistance (Xu et al., 2016). Third, exosomal ncRNA has been recently reported with a therapeutic role. Marleau et al. (2012) reported that pathogenic exosomal ncRNA can reduce the number of exosomes by inhibiting its sorting pathway or by blood filtration. Based on the sponge function of circRNA, artificial circRNA sponges loaded with exosomes have been designed to target pathogenic miRNA in diseases (Geng et al., 2020).

As another cargo category in exosomes, proteins can actually provide more direct information about disease progression. Interestingly, exosomes of different cellular origin share certain common protein components, such as tetraspanins (CD63, $\mathrm{CD} 9, \mathrm{CD} 81$, and $\mathrm{CD} 82$ ), integrins proteins, membrane fusion proteins, and several molecular chaperones (HSP70 and 90) (Pegtel and Gould, 2019). Like the exosomal ncRNAs in disease diagnosis, exosomal proteins have been demonstrated with higher sensitivity, specificity, and stability than traditional serum markers. In breast cancer patients, more than 100 phosphoproteins in plasma exosome were detected with diagnostic value (Chen et al., 2017). In cancer research, Glypican1 (GPC1) in exosomes effectively helped to identify pancreatic cancer patients (Melo et al., 2015). Besides, by transporting functional proteins, exosomes can also participate in the progression of disease. Recently, exosomal PD-L1 has been 


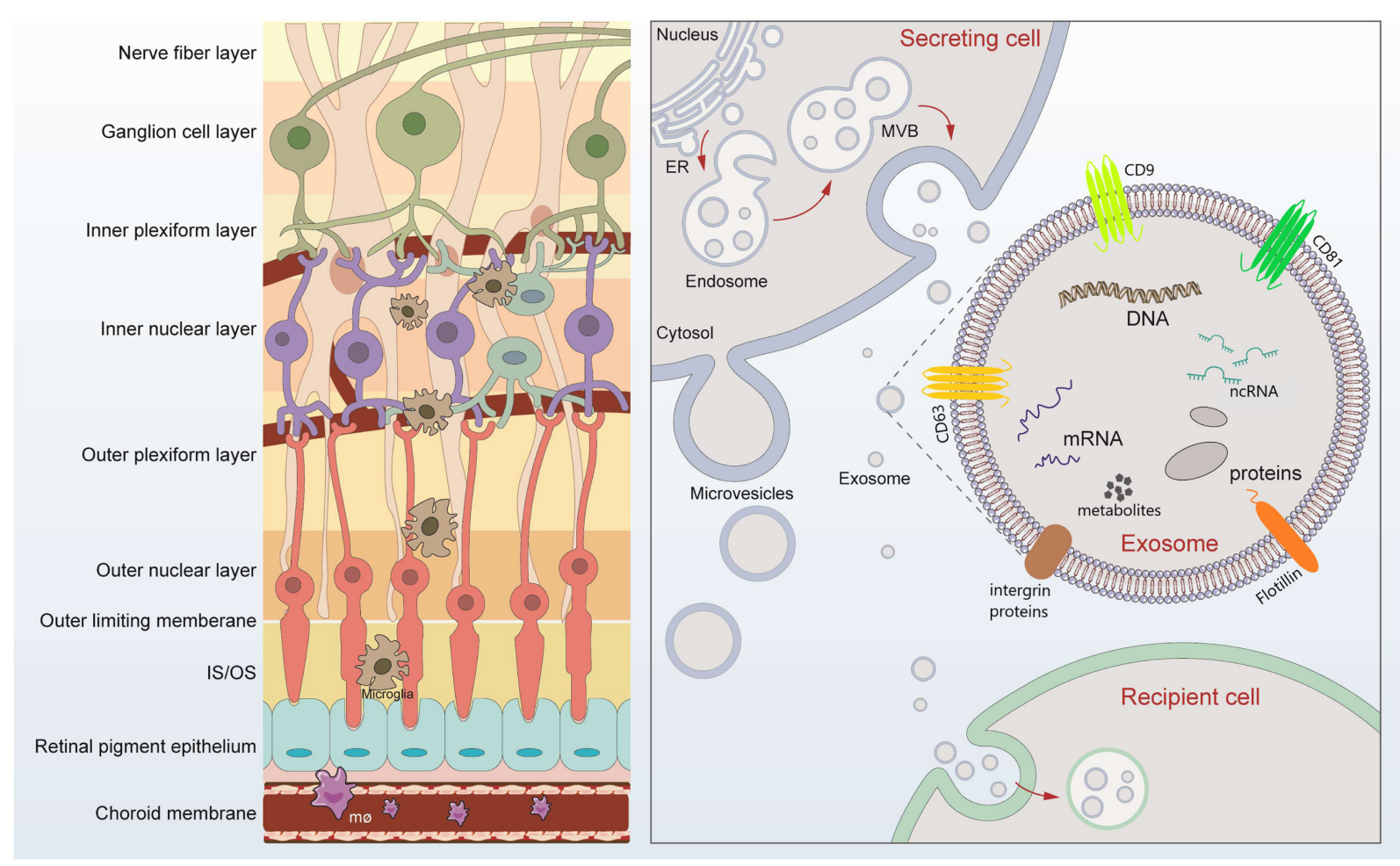

FIGURE 1 | Retinal layers and schematic signaling transferred by exosomes. Retina can be roughly divided into nine layers, which tightly contact lay by lay. Exosomes are released after fusion of multivesicular bodies (MVBs) with the plasma membrane. The lipid bilayer of exosomes contains specific lipids such as cholesterol and phosphatidylserine, which protect the contents from degeneration. The cargos loaded by exosomes includes microRNAs, long-non-coding RNAs, DNA, message RNA, lipids, metabolites, and proteins, mediating possible exchange among different retinal cells. Exosomes of different cellular origin share certain common protein components such as CD9, CD81, and CD63.

indicated to mediate immune escape of tumor cells (Ricklefs et al., 2018); exosomal clusterin can improve myocardial performance and protect cell survival in mouse myocardial infarction model (Foglio et al., 2015); and inhibition of exosome MCP-1 expression can effectively protect retinal cell activity (Yu et al., 2016). By modifying the exosome surface protein by genetic engineering (Liu and Su, 2019), the exosome acts as a therapeutic tool. For example, exosomes with hyaluronidase $\mathrm{PH} 20$ on their membrane can activate dendritic cells (DC) to promote anti-cancer immune response (Hong et al., 2019). Another example is that exosome with high expression of MHC class I/peptide complexes can effectively activate CD8 (+) T cells (André et al., 2004).

In addition to constituting exosomal membranes, specific lipids (e.g., cholesterol, phospholipids, and phosphatidylserine) have been investigated and enriched in exosomes compared to their parent cells (Skotland et al., 2017). Notably, there are several similarities between the lipid composition of exosomes, HIV particles, and detergent resistant membranes (DRMs), isolated from cells as models for lipid rafts (Llorente A. et al., 2013; Lorizate M. et al., 2013). The first study of lipid biomarkers in exosomes was performed with urinary samples from eight patients with renal cell carcinoma and eight healthy volunteers (Lorizate M. et al., 2013). Subsequently, such studies have been reported on the diagnosis of prostate cancer (Clos-Garcia et al., 2018). To our knowledge, there has been no research on exosomal lipid as diagnosis biomarker for retinal diseases.

For exosomal small molecular substances, most studies have focused on the loading of chemotherapeutic drugs in exosome, such as incubation of paclitaxel with mesenchymal stem cell (MSC)-derived exosomes to inhibit tumor growth (Pascucci et al., 2014), catalase loading into exosomes to treat Parkinson's disease (PD) (Haney et al., 2015).

\section{EXOSOMES IN RETINAL DISEASE}

Although exosomes have been intensively investigated in cancer and cardiovascular diseases, its role in retinal diseases has not been fully studied. Owing to the relatively small volume vitreous and aqueous humor can be obtained, and for ethic issues, most research is still at the stage, mainly performed in vitro. On the other hand, retina, as the immune-privileged site, which is protected from external and internal insults by its bloodretina barriers and immune suppressive microenvironment, is actually an ideal target tissue for exosome-based therapies (Nam et al., 2020).

Under pathologic conditions, inflammation, oxidative stress, immune response, etc., exosomes can be generated by retinal cells, and secreted into extracellular spaces or vitreous cavity 
TABLE 1 | Strategies for exosome separation.

\begin{tabular}{|c|c|c|c|}
\hline $\begin{array}{l}\text { Isolation } \\
\text { strategy }\end{array}$ & Principle & Advantages & Disadvantages \\
\hline $\begin{array}{l}\text { Differential } \\
\text { ultracentrifugation }\end{array}$ & $\begin{array}{l}\text { Particles with } \\
\text { different density, size } \\
\text { and mass show } \\
\text { different deposition } \\
\text { rates under } \\
\text { centrifugal force. }\end{array}$ & $\begin{array}{l}\text { - Suitable for mass } \\
\text { preparation } \\
\text { - Low cost }\end{array}$ & $\begin{array}{l}\text { - Centrifuge } \\
\text { equipment } \\
\text { needed } \\
\text { - Time-consuming } \\
\text { - Risk of } \\
\text { contamination }\end{array}$ \\
\hline $\begin{array}{l}\text { Density-gradient } \\
\text { separation }\end{array}$ & $\begin{array}{l}\text { Exosomes further } \\
\text { separated by } \\
\text { density in density } \\
\text { gradient media }\end{array}$ & - High purity & $\begin{array}{l}\text { - More complex } \\
\text { operations } \\
\text { - Time-consuming }\end{array}$ \\
\hline Ultrafiltration & $\begin{array}{l}\text { Selective separation } \\
\text { of exosomes with } \\
\text { specific particle size } \\
\text { by using a filter } \\
\text { membrane with a } \\
\text { specific molecular } \\
\text { weight interception } \\
\text { value }\end{array}$ & $\begin{array}{l}\text { - Low cost } \\
\text { - Fast procedure } \\
\text { - High purity of } \\
\text { products }\end{array}$ & $\begin{array}{l}\text { - Exosome } \\
\text { membrane } \\
\text { blockage } \\
\text { - Exosome } \\
\text { deformation }\end{array}$ \\
\hline $\begin{array}{l}\text { Size exclusion } \\
\text { chromatography }\end{array}$ & $\begin{array}{l}\text { Particles are eluted if } \\
\text { larger than pore size } \\
\text { of the porous } \\
\text { polymer }\end{array}$ & $\begin{array}{l}\text { - High purity of } \\
\text { products } \\
\text { - Fast procedure } \\
\text { - Suitable for } \\
\text { blood plasma } \\
\text { - Maintain the } \\
\text { shape of } \\
\text { exosome }\end{array}$ & $\begin{array}{l}\text { - Low output } \\
\text { - Limited in large } \\
\text { samples. }\end{array}$ \\
\hline Co-precipitation & $\begin{array}{l}\text { The highly } \\
\text { hydrophilic polymer } \\
\text { interacts with the } \\
\text { water molecules } \\
\text { around the exosome } \\
\text { to reduce the } \\
\text { solubility of } \\
\text { exosomes, resulting } \\
\text { in precipitation }\end{array}$ & $\begin{array}{l}\text { - Easy to use } \\
\text { - Low equipment } \\
\text { requirement } \\
\text { - Fast procedure }\end{array}$ & $\begin{array}{l}\text { - Protein pollution } \\
\text { - Require } \\
\text { complicated } \\
\text { clean-up steps }\end{array}$ \\
\hline $\begin{array}{l}\text { Immunoaffinity } \\
\text { capture }\end{array}$ & $\begin{array}{l}\text { Based on the } \\
\text { specific binding of } \\
\text { exosome surface } \\
\text { protein markers to } \\
\text { the corresponding } \\
\text { antibodies }\end{array}$ & $\begin{array}{l}\text { - Isolation of } \\
\text { exosomes from } \\
\text { specific sources } \\
\text { - High purity of } \\
\text { products }\end{array}$ & $\begin{array}{l}\text { - High-cost } \\
\text { antibodies } \\
\text { - Low output }\end{array}$ \\
\hline
\end{tabular}

(Fukushima et al., 2020). In addition, the exosomes from remote cells or hematopoietic cells in patient with systematic diseases can also exert possible harmful effect on retina (Aires et al., 2020). Table 2 summarized the studies concerning the exosomes in retinal diseases.

\section{Age-Related Macular Degeneration}

Age-related macular degeneration (AMD) is the leading cause of vision loss in the elderly in Europe and the United States. The disease mostly occurs at the age of about 50 years old. With the older the age, the higher the incidence is. The pathogenesis of early AMD is characterized by the physiological phagocytosis of outer segments by retinal pigment epithelium (RPE) cells and the accumulation of excretion of residual metabolites from RPE cells to form drusen. Some studies have shown that the exosome surface proteins such as CD63, CD81, and LAMP2 expressed in the drusen of AMD patients (Wang et al., 2009). Meanwhile, it was also found that CD63 was co-located with the common proteins in drusen, suggesting that exosomes may coexcreted along with other metabolites from RPE cells. Ebrahimi et al. (2014) found that exosome participates in the release of complement regulatory factor RPE cells, such as CD46 and CD59, and this dysregulation the complement system plays important roles in the development of AMD. Photoreceptor cell death and microglia activation are also known to occur progressively in dry AMD pathogenesis. There is an inverse correlation between exosome concentration and photoreceptor survivability, with a decrease of exosome numbers following photoreceptor damage (Wooff et al., 2020). Using co-culture of RPE and retinal microglia, Morris et al. (2020). demonstrated that miR-21 was transferred from RPEs to microglia, which can further influence the expression of genes downstream of the p53 pathway in microglia.

$\alpha \mathrm{B}$ crystallin is a small heat shock protein (HSP), which is known to be expressed in a variety of tissues in vivo. In retina, $\alpha \mathrm{B}$ crystallin mainly exists in mitochondria and cytoplasm of RPE cells and participates in neuroprotection and regulation of angiogenesis (Kase et al., 2010; Kannan et al., 2012). Kannan et al. (2016) showed that $\alpha \mathrm{B}$ crystallin can protect RPE cells from oxidative damage. The $\alpha \mathrm{B}$ crystallin is also a regulator of angiogenesis and vascular endothelial growth factor (Kase et al., 2010). However, under pathological conditions, PRE cells can secrete exosomes loaded with $\alpha \mathrm{B}$ crystallin, which further and promote the formation of drusen (De et al., 2007).

Oxidative stress plays important role in RPE proinflammatory damage. Nod-like receptor protein 3 (NLRP3) inflammasome has the capability to sense the reactive oxide species (ROS) produced by mitochondrial dysfunction, and further to activate caspase-1, promoting the precursor maturation of inflammatory cytokines IL-1 $\beta$ and IL-18. Tarallo et al. (2012) and Kim et al. (2014) reported the activation of NLRP3 in RPE cells from patients with AMD. On the basis of this, Zhang et al. (2019b) found that the expression of IL-1 $\beta$, IL-18, and caspase1 was up-regulated in exosomes isolated from APRE-19 under photooxidative blue-light stimulation, which demonstrated the role of exosomes in the regulation of NLRP3 inflammatory bodies. On the other hand, oxidative stress can not only promote the release of exosomes from RPEs, but also make receptor cells engulf exosomes more quickly in the progression of AMD disease (Nicholson et al., 2020a; Yang et al., 2020). Exosomes under oxidative stress can also increase apoptosis of ARPE-19 cells through overexpression of Apaf1 and induce oxidative damage and inflammation through caspase-9 apoptosis pathway (Ke et al., 2020). In another study exosome from J-cybrids reduced transepithelial resistance (TER) in receptor ARPE-19 cells, and this is associated with high risk of AMD (Nicholson et al., 2020b). Similarly, the mitochondrial damage of ARPE-19 could lead to an increase in the level of miR-494-3p in exosome (Ahn et al., 2020), which may be helpful for early diagnosis of AMD.

In wet $\mathrm{AMD}$, abnormal choroidal neovascularization (CNV) is the hallmark that sprouts from the choroid vasculature and grows beneath and into the retina. Recently, Fukushima et al. (2020) reported that epithelial-mesenchymal transition (EMT) 
TABLE 2 | A selective overview of studies reporting exosomes in retina diseases.

\begin{tabular}{|c|c|c|c|c|c|}
\hline References & Origin of exosomes & Disease involved & Exosomal cargo & Biological function & $\begin{array}{l}\text { Year of } \\
\text { publication }\end{array}$ \\
\hline Inoue et al. (2007) & $\begin{array}{l}\text { Mouse bone marrow } \\
\text { MSCs }\end{array}$ & $\mathrm{RD}$ & NA & Delay of the photoreceptor apoptosis & 2007 \\
\hline $\begin{array}{l}\text { Hajrasouliha et al. } \\
\text { (2013) }\end{array}$ & Retinal astroglial cells & Laser-induced CNV & $\begin{array}{l}\text { Endostatin, } \\
\text { CXCL-1, MIP-1 } 1 \alpha \\
\text { MMP MMP-3, } \\
\text { MMP-9, Nov, PEDF }\end{array}$ & Inhibition of CNV & 2013 \\
\hline Ragusa et al. (2015) & $\begin{array}{l}\text { Vitreous humor and } \\
\text { serum }\end{array}$ & Uveal melanoma & $\begin{array}{l}\text { miR-21, miR-34a, } \\
\text { miR-146a }\end{array}$ & Promotion the proliferation of tumor cells & 2015 \\
\hline Yu et al. (2016) & $\begin{array}{l}\text { Mouse adipose } \\
\text { MSCs and human } \\
\text { umbilical cord MSCs }\end{array}$ & Retinal laser injury & NA & $\begin{array}{l}\text { Down-regulation of MCP-1 and alleviation } \\
\text { of laser induced retinal injury. }\end{array}$ & 2016 \\
\hline Kannan et al. (2016) & $\mathrm{RPE}$ & AMD & $\alpha \mathrm{B}$-Crystallin & $\begin{array}{l}\text { Neural protection for adjacent RPE cells } \\
\text { and photoreceptors. }\end{array}$ & 2016 \\
\hline $\begin{array}{l}\text { Knickelbein et al. } \\
\text { (2016) }\end{array}$ & ARPE-19 & $\mathrm{RD}$ & $\begin{array}{l}\text { Proinflammatory } \\
\text { cytokines }\end{array}$ & Inhibition of $\mathrm{T}$ cell proliferation & 2016 \\
\hline $\begin{array}{l}\text { Mead and Tomarev } \\
\text { (2017) }\end{array}$ & $\begin{array}{l}\text { Human bone marrow } \\
\text { MSCs }\end{array}$ & Optic nerve crush & NA & Neuroprotection and neurogenesis & 2017 \\
\hline $\begin{array}{l}\text { Shigemoto-Kuroda } \\
\text { et al. (2017) }\end{array}$ & MSCs & $\begin{array}{l}\text { Type } 1 \text { diabetes and } \\
\text { experimental } \\
\text { autoimmune } \\
\text { uveoretinitis }\end{array}$ & TSG-6 & $\begin{array}{l}\text { Inhibition of the activation of } \\
\text { antigen-presenting cells and inhibition of } \\
\text { the development of Thelper } 1 \text { (Th1) and } \\
\text { Th17 cells }\end{array}$ & 2017 \\
\hline Huang et al. (2018) & Plasma & DR & igG & Promotion of microvascular damage & 2018 \\
\hline Safwat et al. (2018) & Rabbit adipose MSCs & $\mathrm{DR}$ & miR-222 & Reduction of retinal degeneration & 2018 \\
\hline Zhang et al. (2018) & $\begin{array}{l}\text { Human umbilical cord } \\
\text { MSCs }\end{array}$ & Macular holes & & $\begin{array}{l}\text { Promotion of the functional and anatomical } \\
\text { recovery of macular hole }\end{array}$ & 2018 \\
\hline Zhang et al. (2019b) & $\begin{array}{l}\text { ARPE-19 under } \\
\text { stress }\end{array}$ & AMD & $\begin{array}{l}\mathrm{IL}-1 \beta, \mathrm{IL}-18 \text {, and } \\
\text { caspase-1 }\end{array}$ & Upregulation of NLRP3 inflammasome & 2019 \\
\hline Liu et al. (2019) & $\begin{array}{l}\text { Human retinal } \\
\text { pericytes } \\
\text { (ACBRI-183) }\end{array}$ & $\mathrm{DR}$ & cPWWP2A & $\begin{array}{l}\text { Regulation of retinal microvascular function } \\
\text { by Mir-579/ingiogenin 1/occludin/SIRT1 } \\
\text { pathway }\end{array}$ & 2019 \\
\hline Liu et al. (2019) & $\begin{array}{l}\text { Human umbilical cord } \\
\text { MSCs }\end{array}$ & $\begin{array}{l}\text { Hyperglycemia-induced } \\
\text { retinal inflammation }\end{array}$ & $\mathrm{miR}-126$ & $\begin{array}{l}\text { Down-regulation of HMGB1 expression and } \\
\text { NLRP3 inflammasome in HRECs induced } \\
\text { by high glucose }\end{array}$ & 2019 \\
\hline Mathew et al. (2019) & $\begin{array}{l}\text { Human bone marrow } \\
\text { MSCs }\end{array}$ & $\begin{array}{l}\text { Retinal } \\
\text { ischemia-reperfusion }\end{array}$ & NA & $\begin{array}{l}\text { Enhancement of the functional recovery } \\
\text { and reduction of the neuroinflammation and } \\
\text { apoptosis }\end{array}$ & 2019 \\
\hline Zhang et al. (2019a) & Platelet-rich plasma & $\mathrm{DR}$ & CXCL10 & $\begin{array}{l}\text { Upregulation of TLR4 signal pathway and } \\
\text { mediation of hyperglycemia-induced retinal } \\
\text { endothelial injury }\end{array}$ & 2019 \\
\hline Ma et al. (2020) & $\begin{array}{l}\text { Rat bone marrow } \\
\text { MSCs }\end{array}$ & Retinal detachment & NA & $\begin{array}{l}\text { Reduction of the expression of TNF- } \alpha \text { and } \\
\mathrm{IL}-1 \beta \text { and Inhibition of photoreceptor } \\
\text { apoptosis }\end{array}$ & 2020 \\
\hline Bian et al. (2020) & $\begin{array}{l}\text { Neural } \\
\text { stem/progenitor cell }\end{array}$ & $\mathrm{RD}$ & $\begin{array}{l}17 \text { miRNAs } \\
\text { (let-7a-5p, } \\
\text { miR-26a-5p, } \\
\text { miR-21-5p, etc.) }\end{array}$ & $\begin{array}{l}\text { Protection of photoreceptor cells by } \\
\text { inactivating microglia cells }\end{array}$ & 2020 \\
\hline $\begin{array}{l}\text { Nicholson et al. } \\
\text { (2020a) }\end{array}$ & RPES & AMD & $\begin{array}{l}\text { Ligands and } \\
\text { neuraminidase }\end{array}$ & $\begin{array}{l}\text { Promotion of rapid absorption of receptor } \\
\text { cells }\end{array}$ & 2020 \\
\hline Zhang W. et al. (2020) & Platelet-rich plasma & $\mathrm{DR}$ & NA & $\begin{array}{l}\text { Activation of YAP, enhancement of both the } \\
\text { proliferation and fibrogenic activity of Müller } \\
\text { cells via the PI3K/Akt pathway. }\end{array}$ & 2020 \\
\hline Zhu et al. (2020) & Retinal astrocytes & $\mathrm{DR}$ & NA & $\begin{array}{l}\text { Promotion of the proliferation and migration } \\
\text { of endothelial cells }\end{array}$ & 2020 \\
\hline Yang et al. (2020) & ARPE-19 & AMD & NA & $\begin{array}{l}\text { Aggravation of oxidative stress damage in } \\
\text { RPE cells }\end{array}$ & 2020 \\
\hline Ahn et al. (2020) & ARPE-19 & AMD & miR-494-3p & $\begin{array}{l}\text { Potential biomarkers of mitochondrial } \\
\text { dysfunction }\end{array}$ & 2020 \\
\hline Ke et al. (2020) & ARPE-19 & AMD & Apaf1 & $\begin{array}{l}\text { Induction of inflammation and apoptosis in } \\
\text { normal RPE cells via Apaf1/caspase- } 9 \text { axis }\end{array}$ & 2020 \\
\hline
\end{tabular}


TABLE 2 | Continued

\begin{tabular}{|c|c|c|c|c|c|}
\hline References & Origin of exosomes & Disease involved & Exosomal cargo & Biological function & $\begin{array}{l}\text { Year of } \\
\text { publication }\end{array}$ \\
\hline $\begin{array}{l}\text { Fukushima et al. } \\
\text { (2020) }\end{array}$ & ARPE-19 & AMD & Angiogenic factors & Promotion of the angiogenesis & 2020 \\
\hline Morris et al. (2020) & $\mathrm{RPE}$ & AMD & $\operatorname{miR}-21$ & Regulation of microglia function & 2020 \\
\hline $\begin{array}{l}\text { Seyedrazizadeh et al. } \\
\text { (2020) }\end{array}$ & $\begin{array}{l}\text { Human embryonic } \\
\text { stem cells }\end{array}$ & Optic nerve injury & NA & Protection for retinal ganglion cells & 2020 \\
\hline Aires et al. (2020) & Microglia & Glaucoma & NA & $\begin{array}{l}\text { Activation of microglia and induction of cell } \\
\text { death }\end{array}$ & 2020 \\
\hline Gu S. et al. (2020) & ARPE-19 & $\mathrm{DR}$ & $\mathrm{miR}-202-5 p$ & $\begin{array}{l}\text { Inhibition of growth, migration and tube } \\
\text { formation of HUVEC cells }\end{array}$ & 2020 \\
\hline Koh et al. (2020) & $\begin{array}{l}\text { Human } \\
\text { placenta-derived } \\
\text { MSCs }\end{array}$ & Optic nerve injury & NA & $\begin{array}{l}\text { Restore the expression of regeneration } \\
\text { markers in R28 cells injured by hypoxia } \\
\text { damage }\end{array}$ & 2020 \\
\hline Zhang Y. et al. (2020) & ARPE-19 & $\mathrm{DR}$ & $\mathrm{miR}-543$ & Induction of EMT in receptor RPE cells & 2020 \\
\hline $\begin{array}{l}\text { Nicholson et al. } \\
\text { (2020b) }\end{array}$ & ARPE-19 & AMD & $\begin{array}{l}\text { Fibronectin, } \\
\text { annexin A2 }\end{array}$ & $\begin{array}{l}\text { Trigger loss in transepithelial resistance } \\
\text { (TER) in recipient monolayers mediated by } \\
\text { HDAC6 }\end{array}$ & 2020 \\
\hline Yan et al. (2020) & Human 293T cells & Retinal ischemia & NA & Neuroprotective effect & 2020 \\
\hline Gu C. et al. (2020) & Adipose MSCs & $\mathrm{DR}$ & miR-192 & Negative regulation of ITGA1 & 2020 \\
\hline Li et al. (2021) & $\begin{array}{l}\text { Human umbilical cord } \\
\text { MSCs }\end{array}$ & CNV & $\mathrm{miR}-27 \mathrm{~b}$ & $\begin{array}{l}\text { Inhibition of EMT and subretinal fibrosis by } \\
\text { targeting HOXC6 }\end{array}$ & 2021 \\
\hline Wang et al. (2021) & ARPE-19 & $\mathrm{RD}$ & NA & $\begin{array}{l}\text { Protect the photoreceptor and inhibit the } \\
\text { expression of inflammatory factors, reduce } \\
\text { the oxidative damage. }\end{array}$ & 2021 \\
\hline
\end{tabular}

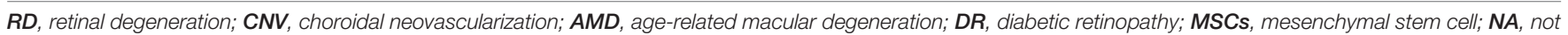
available, not mentioned in the article; RPE, Retinal Pigment Epithelium; EMT, epithelial-mesenchymal transformation.

related factors can promote RPE cells to secrete exosome enriched of angiogenic factors, thus promoting the progress of CNV. On the contrary, the miR-27b derived from human umbilical cord mesenchymal stem cells can inhibit EMT by targeting HOXC6, thus delaying the progress of CNV (Li et al., 2021).

\section{Glaucoma and Optic Nerve Crush}

Glaucoma is a disease characterized by optic papilla atrophy, visual field defect, and vision loss. The main mechanism of glaucoma is the chronic death of retinal ganglion cell (RGC), which is driven by many factors, such as high intraocular pressure. Reported pathological processes involved in RGCs death included neurotrophic factor deprivation, toxic pro-neurotrophins, mitochondrial dysfunction, activation of apoptotic signals, oxidative stress, and loss of synaptic connectivity (Almasieh et al., 2012). Exosome has also recently been indicated to play an important role in the process of glaucoma. Aires et al. (2020) reported that exosomes produced by retinal microglia under high intraocular pressure can propagate the inflammatory signals and promote retinal degeneration. Another two groups found that exosome derived from human placental MSCs and human 293T cells which express brainderived neurotrophic factor (BDNF) can protect R28 cells (retinal precursor cells that represent RGCs) from hypoxia injury (Koh et al., 2020; Yan et al., 2020).

Optic nerve crush, as another animal model of glaucoma, is accompanied by the injury of retinal ganglion cells and axons. Previous studies have shown that MSC can effectively delay the apoptosis of RGC (Inoue et al., 2007). In a recent study, Mead and Tomarev (2017) isolated and injected MSCs-derived exosomes into the rat vitreous and showed that the exosomes successfully transported its neuroprotective cargos into RGC cells in maintaining the retinal function. Similarly, exosome derived from umbilical cord mesenchymal stem cells (UMSCs) and human embryonic stem cells (ES-MSCs) have also been found to yield similar neuroprotective effects (Pan et al., 2019; Seyedrazizadeh et al., 2020). In addition, Tassew et al. (2017) found that exosomes derived from fibroblasts can promote axonal regeneration by activating autocrine Wnt10b-mTOR pathway. These studies have collectively shown the therapeutic potential of exosomes in glaucoma and optic neuropathy.

\section{Diabetic Retinopathy (DR)}

Diabetic retinopathy is one of the most common microvascular complications of diabetes mellitus. Vascular endothelial growth factor (VEGF) increases the permeability of retinal capillaries and macular edema, deteriorating the visual acuity. Under physiological condition, there is a balance between pro- and antiangiogenic components in the eye. Hajrasouliha et al. (2013) found that exosomes released from retinal cells contain proangiogenic components, while exosomes from retinal astroglia cells (RACs) contain anti-angiogenic components. However, under oxidative stress, the exosomes released by RACs can promote the proliferation and migration of endothelial cells (Zhu et al., 2020). Similarly, exosomes derived from platelet-rich plasma (PRP-Exos) can also mediate retinal endothelial injury 
by up-regulating TLR4 signaling pathway (Zhang et al., 2019a). Besides, PRP-Exos can also promoted the proliferation and fibrosis of Müller cells (Zhang W. et al., 2020). As endothelialto-mesenchymal transition (EndoMT) being implicated in endothelia dysfunction in DR, Gu S. et al. (2020) found that high glucose (HG)-induced miR-202-5p in exosomes of ARPE-19 cells had a negative regulatory effect on the expression of transforming growth factor $\beta 2$ and inhibited HG-induced EndoMT.

As one of the main cells that make up retinal blood vessels, pericytes, if lost, early damage of the vessel occurs (Hammes et al., 2002). Liu et al. (2019) showed that diabetes-related stress can upregulate the expression of $\mathrm{CPWWP} 2 \mathrm{~A}$ in pericytes. The high level of cPWWP2A loaded within the exosomes can be transferred from pericytes to endothelial cells, leading to the angiogenic alteration of the receptor cells (Liu et al., 2019).

The activation of complement system has also been implicated in the dysfunction of blood-retinal barrier. As reported, the plasma IgG-laden exosomes could activate the classical complement pathway and the quantity of these exosomes was increased in diabetes (Huang et al., 2018). Compared with diabetic mice, STZ-induced diabetic mice that lack the expression of IgG resulted in less retinal vascular leakage (Huang et al., 2018). Further, plasma IgG-laden exosomes has been demonstrated to lead to membrane attack complex (MAC) deposition and contribute to retinal endothelial damage by activating the classical complement pathway (Huang et al., 2020).

The therapeutic potential of exosomes in DR has also been a great concern for researchers. Exosome of adipose MSCs containing miR-192 or miR-222 can suppress the inflammatory response and angiogenesis of DR (Safwat et al., 2018; Gu C. et al., 2020). In another research (Zhang et al., 2019c), the researchers injected UMSC-Exos with overexpression of miR-126 into the vitreous of diabetic rats, and found that those exosomes successfully inhibited HMGB1 signaling pathway and alleviated inflammation induced by hyperglycemia.

\section{Autoimmune Uveitis}

Autoimmune uveitis, mainly mediated by antigen-specific $\mathrm{T}$ lymphocytes including Th1 and Th17 cells, is an autoimmune disease involving a number of inflammatory cytokines. Shigemoto-Kuroda et al. (2017) found that MSC-exos can effectively suppress the immune response in mice with experimental autoimmune uveoretinitis (EAU). Compared with the control group injected with PBS, pro-inflammatory cytokines, IFN- $\gamma+\mathrm{CD} 4+$ cells, and IL-17+CD4+cells were significantly decreased in MSC-exos injection group. On the other hand, Knickelbein et al. (2016) demonstrated that exosomes produced by RPEs and peripheral blood monocytes from patients with non-infective uveitis could significantly inhibited the proliferation of $\mathrm{T}$ cells. In EAU mice model, Kang et al. (2020) found that exosomes derived from IL-35-producing regulatory B-cells can induce the expansion of IL-10-producing $\mathrm{T}$ cells (Tregs), and IL-35-producing T cells (iTR35), alleviating the autoimmune uveoretinitis in mice (Dambuza et al., 2017). In clinic, Zheng et al. (2020) conducted a proteomic analysis of exosomes in patients with Vogt-Koyanagi-Haradasyndrome $(\mathrm{VKH})$ disease and found that the levels of carbonic anhydrase
2 and RAS-related protein Rap-1b can be used as biomarkers to predict active inflammation of $\mathrm{VKH}$ disease. However, further studies are needed to investigate how the exosomes from the body provoke the ocular autoimmune pathogenesis.

\section{Other Retinal Diseases}

Retinal laser injury is a kind of thermal injury that directly burns the retina. In a mouse model of retinal injury induced by laser, intravenous injection of MSC can inhibit retinal cell apoptosis (Jiang et al., 2014). Further experiments showed that monocyte chemotactic protein (MCP)-1 in retina was significantly downregulated by intravitreal injection of MSC-exos, and both MSCexos and MSC could reduce apoptosis of retinal cells. At the same time, blocking the expression of MCP-1 can effectively protect the viability of retinal cells, indicating that MSC-exos can reduce retinal injury by targeting MCP-1 (Yu et al., 2016).

Macular hole (MH), which is defined as a full-thickness defeat in the neuroretina of the macula. Vitrectomy with ILM peeling or inverting is the main method for anatomical reduction, but the functional recovery is not satisfactory. Few literatures on the treatment of macular holes with stem cells-derived exosomes can be obtained. Zhang et al. (2018) investigated the efficacy of postoperative injection of MSC $(n=2)$ or MSC-exos $(n=5)$ in the treatment of seven patients with refractory macular hole. The results showed that the BCVA of five closed-hole eyes improved after operation. Compared with MSC-exos injection, one patient with MSC injection showed a epiretinal fibrous membrane. However, the limitation of this study lies in the small number of patients and the control group, and further research is needed to evaluate the actual therapeutic effect.

Retinal detachment (RD) is defined as the separation of the neurosensory retina from the RPEs. Ma et al. (2020) found that MSC-Exos have therapeutic effects on reducing retinal inflammation, enhancing autophagy, and inhibiting photoreceptor cell apoptosis in a rat RD model. Further exosomal proteins analysis identified a total of 683 independent proteins, among which 9 proteins that may play anti-inflammatory, neuroprotective and anti-apoptotic effects in this RD model.

Ocular malignant tumor is a life-threatening disease, usually because of its easy recurrence, and high rate of metastasis. In the past few years, the role of exosomes in cancer field has been much stressed. The exosomes can not only participate in tumor angiogenesis (Zeng et al., 2019), but also promote tumor growth and tumor metastasis (Biswas and Acharyya, 2020). In the research of Eldh et al. (2014), the exosomes isolated from the liver perfusion fluid of patients with metastatic uveal melanoma were found to carry positive melanoma-specific marker Melan-A, indicating that there were exosomes of tumor origin in the liver perfusion. In addition, Ragusa et al. (2015) found that compared with the control group, there were upregulated expressions of miR-21, -34a, -146a in vitreous and vitreous exosomes, and there were upregulated miR-146a in serum and exosomes of UM patients. In a more recent study, the authors performed proteomic analysis of exosomes derived from retinoblastoma and identified that several proteins were involved in extracellular matrix (ECM) remodeling, and the metabolism/catabolism of glucose and amino acids (Galardi et al., 2020). These two 
studies make it an expectant method to diagnose eye tumor by collecting periocular tissue or body fluid samples and detecting the specific exosomes.

\section{EXOSOMES AS THERAPEUTIC AGENTS}

The conventional route of treatment for eye disease usually needs the frequent administration of topical instillation of eye drops which has low bioavailability. Although various synthetic drug vehicles have been recently developed for encasing existing drugs to enhance the therapeutic effect (Kompella et al., 2020), troubling issues should keep in mind including their immunotoxicity (Pandey and Prajapati, 2018) and quick clearance by the mononuclear phagocyte system or the reticuloendothelial system (Haque et al., 2016). Fortunately, exosomes, reported as natural nanocarriers to deliver drugs/nucleic acids, providing several. First of all, exosomes are naturally present in body fluids so that they are stable under both physiological and pathological conditions. As reported, immune related miRNA derived from human breast milk are shown to be very stable in very acidic conditions, thus tolerating an infant's gastrointestinal environment (Kosaka et al., 2010). Second, exosomes are less toxic and immunogenic compared to other carriers. For example, both viral and nonviral carriers have been developed as gene delivery vehicles in retinal diseases, however, they have major drawbacks such as a high systematic toxicity and trigger immune response (Verdera et al., 2020). Compared with intravitreal injection of traditional adeno-associated virus 2 (AAV2), the novel exosome-associated AAV2 (exo-AAV2) revealed that exo-AAV2 carrying the GFPcoding gene AAV was more strongly expressed and had greater penetrability in the retina (Wassmer et al., 2017). Compared with MSCs themselves used to treat various diseases, exosomebased therapeutics have a lower risk for teratoma formation and embolization, which are major concerns for stem cell-based therapeutics (Shigemoto-Kuroda et al., 2017; Pan et al., 2019; Seyedrazizadeh et al., 2020). Third, due to unique membrane proteins and lipids that bind to specific receptors on the recipient cell surface, exosomes are driven to deliver cargo to specific recipient cells, hence, enhancing the delivery efficiency (AlvarezErviti et al., 2011). Finally, exosomes are able to penetrate the biological barriers including the blood-brain barrier (BBB) and the blood-retina barrier (BRB), a major challenge in systemic drug delivery research as most drugs and carriers cannot cross this barrier (Elliott and He, 2021; Figure 2).

Inspired by these advantages and their ability to transfer regulatory molecules, investigators are developing several strategies for the treatment of retinal diseases via exosomes. Hajrasouliha et al. (2013) reported that the exosomes of retinal astrocytes can reduce vascular leakage and inhibit experimental CNV. The exosome of PRE cells can regulate immune response and protect photoreceptor cell (Knickelbein et al., 2016; Wang et al., 2021). In a recent research, exosomes derived from neural stem/progenitor cells (NPCs) were injected into the subretinal space of rats with retinal degeneration, and those NPC-exos were found to significantly inhibit the activation of microglia and protect photoreceptors from apoptosis (Bian et al., 2020). Exosomes from stem cells, such as MSCs, can also play an important role in improving retinal laser injury (Yu et al., 2016), high glucose-induced retinal inflammation (Zhang et al., 2019c), and inhibiting the migration of EAU inflammatory cells (Bai et al., 2018). Similarly, The exosomes of human BMSCs also show promising therapeutic potential in neuroprotection (Mead and Tomarev, 2017), improvement of retinal ischemia (Mathew et al., 2019), and protection from photoreceptor apoptosis (Bian et al., 2020).

Notably, exosomes as a therapeutic agent also have some issues to be overcome. Firstly, a great difficulty for their translation to the clinic would be the low productivity of exosomes obtained with almost all the isolation methods, and also the presence of some impurities such as proteins or other extracellular vesicles. Secondly, though the exosome plays certain therapeutic role, most of their therapeutic function were demonstrated in vivo and the long-term effect is uncertain. Thus, how to demonstrate and maintain the long-term therapeutic effect is also an urgent problem to be solved. Thirdly, the key components which function were not identified in most stem-cell based exosome studies (Mead and Tomarev, 2017; Greening and Simpson, 2018; Huang et al., 2018; Zhang et al., 2018; Mathew et al., 2019;

\section{Exosome based therapy in treatment of retina diseases}

\section{Advantages}

- High stability

- Low toxicity and immunogenicity

- Enhanced delivery efficiency

- High penetration

\section{Disadvantages}

- Low productivity

- Unclear long-term effect

- Unclear therapeutic components

FIGURE 2 | Advantages and disadvantages of exosome-based therapy in treatment of retinal diseases. 
Pan et al., 2019; Ma et al., 2020; Figure 2). To identify the key components in therapeutic exosomes might be helpful for the preparation of exosomes with more efficiency. Besides, in animal models, the exosome is usually injected into the vitreous or subretinal space to explore its therapeutic effect, but there is still a long way to go for the exploration of the relationship between the best therapeutic effect and the injection way, the frequency, and the dose. In the future, more in-depth research can be done on the way of drug administration of the exosomes.

\section{CONCLUSION}

Taken together, exosome research in the eye field is trailing other fields in exosome research, awaiting more extensive investigations to dedicate exosomes in retinal pathogenic process and their attractive diagnostic and therapeutic roles in retinal diseases. However, there is still a long way to the successful translation into clinical therapies before novel technology for mass highly purified exosomes with stable long-term functional efficacy, and elucidation of the key components of exosomes and understanding how each of them. Anyway, we believe that with the future in-depth study of exosomes and the development of novel technologies in retinal diseases, we can have a better

\section{REFERENCES}

Ahn, J. Y., Datta, S., Bandeira, E., Cano, M., Mallick, E., Rai, U., et al. (2020). Release of extracellular vesicle miR-494-3p by ARPE-19 cells with impaired mitochondria. Biochim. Biophys. Acta Gen. Subj. 1865:129598. doi: 10.1016/j. bbagen.2020.129598

Aires, I. D., Ribeiro-Rodrigues, T., Boia, R., Catarino, S., Girão, H., Ambrósio, A. F., et al. (2020). Exosomes derived from microglia exposed to elevated pressure amplify the neuroinflammatory response in retinal cells. Glia 68, 2705-2724. doi: $10.1002 /$ glia. 23880

Alenquer, M., and Amorim, M. J. (2015). Exosome biogenesis, regulation, and function in viral infection. Viruses 7, 5066-5083. doi: 10.3390/v7092862

Almasieh, M., Wilson, A. M., Morquette, B., Cueva Vargas, J. L., and Di Polo, A. (2012). The molecular basis of retinal ganglion cell death in glaucoma. Prog. Retin. Eye Res. 31, 152-181. doi: 10.1016/j.preteyeres.2011.11.002

Alvarez-Erviti, L., Seow, Y., Yin, H., Betts, C., Lakhal, S., and Wood, M. J. (2011). Delivery of siRNA to the mouse brain by systemic injection of targeted exosomes. Nat. Biotechnol. 29, 341-345. doi: 10.1038/nbt.1807

André, F., Chaput, N., Schartz, N. E., Flament, C., Aubert, N., Bernard, J., et al. (2004). Exosomes as potent cell-free peptide-based vaccine. I. dendritic cell-derived exosomes transfer functional MHC class I/peptide complexes to dendritic cells. J. Immunol. 172, 2126-2136. doi: 10.4049/jimmunol.172.4.2126

Bai, L., Shao, H., Wang, H., Zhang, Z., Su, C., Dong, L., et al. (2018). Author correction: effects of mesenchymal stem cell-derived exosomes on experimental autoimmune uveitis. Sci. Rep. 8:9889.

Becker, A., Thakur, B. K., Weiss, J. M., Kim, H. S., Peinado, H., and Lyden, D. (2016). Extracellular vesicles in cancer: cell-to-cell mediators of metastasis. Cancer Cell 30, 836-848. doi: 10.1016/j.ccell.2016.10.009

Bian, B., Zhao, C., He, X., Gong, Y., Ren, C., Ge, L., et al. (2020). Exosomes derived from neural progenitor cells preserve photoreceptors during retinal degeneration by inactivating microglia. J. Extracell. Vesicles 9:1748931. doi: 10.1080/20013078.2020.1748931

Biswas, A. K., and Acharyya, S. (2020). Understanding cachexia in the context of metastatic progression. Nat. Rev. Cancer 20, 274-284. doi: 10.1038/s41568020-0251-4

Chen, I. H., Xue, L., Hsu, C. C., Paez, J. S., Pan, L., Andaluz, H., et al. (2017), Phosphoproteins in extracellular vesicles as candidate markers for breast understanding of the role of exosome in retinal pathogenesis. For patients, the progress of exosome research can be very promising in providing more personalized treatment and diagnosis, so as to shed light on new therapy on treating retinal diseases for years to come.

\section{AUTHOR CONTRIBUTIONS}

$\mathrm{ZZ}, \mathrm{PX}$, and $\mathrm{ZH}$ mainly performed the literature research and drew and revised the manuscript. AM drew the figures and prepared the tables. AF and QL contributed to the discussion and manuscript review. All authors contributed to the article and approved the submitted version.

\section{FUNDING}

This study was supported by the National Natural Science Foundation of China (81870669 to PX, and 81900875 and 12027808 to $\mathrm{ZH}$ ), the Natural Science Foundation of Jiangsu Province (BK20171503 to PX and BK20191059 to ZH), and the Key Project of Research and Development Plan (2017YFA0104101 to QL).

cancer. Proc. Natl. Acad. Sci. U.S.A. 114, 3175-3180. doi: 10.1073/pnas. 1618088114

Clos-Garcia, M., Loizaga-Iriarte, A., Zuñiga-Garcia, P., Sánchez-Mosquera, P., Rosa Cortazar, A., González, E., et al. (2018). Metabolic alterations in urine extracellular vesicles are associated to prostate cancer pathogenesis and progression. J. Extracell. Vesicles 7:1470442. doi: 10.1080/20013078.2018. 1470442

Conigliaro, A., Costa, V., Lo Dico, A., Saieva, L., Buccheri, S., Dieli, F., et al. (2015). CD90+ liver cancer cells modulate endothelial cell phenotype through the release of exosomes containing H19 lncRNA. Mol. Cancer 14:155.

Dambuza, I. M., He, C., Choi, J. K., Yu, C. R., Wang, R., Mattapallil, M. J., et al. (2017). IL-12p35 induces expansion of IL-10 and IL-35-expressing regulatory B cells and ameliorates autoimmune disease. Nat. Commun. 8:719.

de Gassart, A., Geminard, C., Fevrier, B., Raposo, G., and Vidal, M. (2003). Lipid raft-associated protein sorting in exosomes. Blood 102, 4336-4344. doi: 10. 1182/blood-2003-03-0871

De, S., Rabin, D. M., Salero, E., Lederman, P. L., Temple, S., and Stern, J. H. (2007). Human retinal pigment epithelium cell changes and expression of alphaBcrystallin: a biomarker for retinal pigment epithelium cell change in age-related macular degeneration. Arch. Ophthalmol. 125, 641-645. doi: 10.1001/archopht. 125.5.641

Ebrahimi, K. B., Fijalkowski, N., Cano, M., and Handa, J. T. (2014). Oxidized low-density-lipoprotein-induced injury in retinal pigment epithelium alters expression of the membrane complement regulatory factors CD46 and CD59 through exosomal and apoptotic bleb release. Adv. Exp. Med. Biol. 801, 259265. doi: 10.1007/978-1-4614-3209-8_33

Eldh, M., Olofsson Bagge, R., Lässer, C., Svanvik, J., Sjöstrand, M., Mattsson, J., et al. (2014). MicroRNA in exosomes isolated directly from the liver circulation in patients with metastatic uveal melanoma. BMC Cancer 14:962. doi: 10.1186/ 1471-2407-14-962

Elliott, R. O., and He, M. (2021). Unlocking the power of exosomes for crossing biological barriers in drug delivery. Pharmaceutics 13:122. doi: 10.3390/ pharmaceutics13010122

Flaxman, S. R., Bourne, R. R. A., Resnikoff, S., Ackland, P., Braithwaite, T., Cicinelli, M. V., et al. (2017). Global causes of blindness and distance vision impairment 1990-2020: a systematic review and meta-analysis. Lancet Glob. Health 5, e1221-e1234. 
Foglio, E., Puddighinu, G., Fasanaro, P., D’Arcangelo, D., Perrone, G. A., Mocini, D., et al. (2015). Exosomal clusterin, identified in the pericardial fluid, improves myocardial performance following MI through epicardial activation, enhanced arteriogenesis and reduced apoptosis. Int. J. Cardiol. 197, 333-347. doi: 10. 1016/j.ijcard.2015.06.008

Frank, F., Sonenberg, N., and Nagar, B. (2010). Structural basis for $5^{\prime}$-nucleotide base-specific recognition of guide RNA by human AGO2. Nature 465, 818-822. doi: 10.1038/nature09039

Fukushima, A., Takahashi, E., Saruwatari, J., Tanihara, H., and Inoue, T. (2020). The angiogenic effects of exosomes secreted from retinal pigment epithelial cells on endothelial cells. Biochem. Biophys. Rep. 22:100760. doi: 10.1016/j.bbrep. 2020.100760

Galardi, A., Colletti, M., Lavarello, C., Di Paolo, V., Mascio, P., Russo, I., et al. (2020). Proteomic profiling of retinoblastoma-derived exosomes reveals potential biomarkers of vitreous seeding. Cancers 12:1555. doi: 10.3390/ cancers 12061555

Gangalum, R. K., Atanasov, I. C., Zhou, Z. H., and Bhat, S. P. (2011). AlphaBcrystallin is found in detergent-resistant membrane microdomains and is secreted via exosomes from human retinal pigment epithelial cells. J. Biol. Chem. 286, 3261-3269. doi: 10.1074/jbc.m110.160135

Geng, X., Lin, X., Zhang, Y., Li, Q., Guo, Y., Fang, C., et al. (2020). Exosomal circular RNA sorting mechanisms and their function in promoting or inhibiting cancer. Oncol. Lett. 19, 3369-3380.

Goldie, B. J., Dun, M. D., Lin, M., Smith, N. D., Verrills, N. M., Dayas, C. V., et al. (2014). Activity-associated miRNA are packaged in Maplb-enriched exosomes released from depolarized neurons. Nucleic Acids Res. 42, 9195-9208. doi: 10.1093/nar/gku594

Greening, D. W., and Simpson, R. J. (2018). Understanding extracellular vesicle diversity - current status. Expert Rev. Proteomics 15, 887-910. doi: 10.1080/ 14789450.2018.1537788

Gu, C., Zhang, H., and Gao, Y. (2020). Adipose mesenchymal stem cells-secreted extracellular vesicles containing microRNA-192 delays diabetic retinopathy by targeting ITGA1. J. Cell. Physiol. doi: 10.1002/jcp.30213

Gu, S., Liu, Y., Zou, J., Wang, W., Wei, T., Wang, X., et al. (2020). Retinal pigment epithelial cells secrete miR-202-5p-containing exosomes to protect against proliferative diabetic retinopathy. Exp. Eye Res. 201:108271. doi: 10. 1016/j.exer.2020.108271

Guduric-Fuchs, J., O’Connor, A., Camp, B., O’Neill, C. L., Medina, R. J., and Simpson, D. A. (2012). Selective extracellular vesicle-mediated export of an overlapping set of microRNAs from multiple cell types. BMC Genomics 13:357. doi: 10.1186/1471-2164-13-357

Gurunathan, S., Kang, M. H., Jeyaraj, M., Qasim, M., and Kim, J. H. (2019). Review of the isolation, characterization, biological function, and multifarious therapeutic approaches of exosomes. Cells 8:307. doi: 10.3390/cells8040307

Hajrasouliha, A. R., Jiang, G., Lu, Q., Lu, H., Kaplan, H. J., Zhang, H. G., et al. (2013). Exosomes from retinal astrocytes contain antiangiogenic components that inhibit laser-induced choroidal neovascularization. J. Biol. Chem. 288, 28058-28067. doi: 10.1074/jbc.m113.470765

Hammes, H. P., Lin, J., Renner, O., Shani, M., Lundqvist, A., Betsholtz, C., et al. (2002). Pericytes and the pathogenesis of diabetic retinopathy. Diabetes 51, 3107-3112. doi: 10.2337/diabetes.51.10.3107

Haney, M. J., Klyachko, N. L., Zhao, Y., Gupta, R., Plotnikova, E. G., He, Z., et al. (2015). Exosomes as drug delivery vehicles for Parkinson's disease therapy. J. Control. Release 207, 18-30.

Haque, S., Whittaker, M. R., McIntosh, M. P., Pouton, C. W., and Kaminskas, L. M. (2016). Disposition and safety of inhaled biodegradable nanomedicines: opportunities and challenges. Nanomedicine 12, 1703-1724. doi: 10.1016/j. nano.2016.03.002

Hong, Y., Kim, Y. K., Kim, G. B., Nam, G. H., Kim, S. A., Park, Y., et al. (2019). Degradation of tumour stromal hyaluronan by small extracellular vesicle-PH20 stimulates CD103 dendritic cells and in combination with PD-L1 blockade boosts anti-tumour immunity. J. Extracell. Vesicles 8:1670893. doi: 10.1080/ 20013078.2019.1670893

Howard, J., Wyse, C., Argyle, D., Quinn, C., Kelly, P., and McCann, A. (2020). Exosomes as biomarkers of human and feline mammary tumours; a comparative medicine approach to unravelling the aggressiveness of TNBC. Biochim. Biophys. Acta Rev. Cancer 1874:188431. doi: 10.1016/j.bbcan.2020. 188431
Huang, C., Fisher, K. P., Hammer, S. S., and Busik, J. V. (2020). Extracellular vesicle-induced classical complement activation leads to retinal endothelial cell damage via MAC deposition. Int. J. Mol. Sci. 21:1693. doi: 10.3390/ijms210 51693

Huang, C., Fisher, K. P., Hammer, S. S., Navitskaya, S., Blanchard, G. J., and Busik, J. V. (2018). Plasma exosomes contribute to microvascular damage in diabetic retinopathy by activating the classical complement pathway. Diabetes 67, 1639-1649. doi: 10.2337/db17-1587

Inoue, Y., Iriyama, A., Ueno, S., Takahashi, H., Kondo, M., Tamaki, Y., et al. (2007). Subretinal transplantation of bone marrow mesenchymal stem cells delays retinal degeneration in the RCS rat model of retinal degeneration. Exp. Eye Res. 85, 234-241. doi: 10.1016/j.exer.2007.04.007

Inubushi, S., Kawaguchi, H., Mizumoto, S., Kunihisa, T., Baba, M., Kitayama, Y., et al. (2020). Oncogenic miRNAs identified in tear exosomes from metastatic breast cancer patients. Anticancer Res. 40, 3091-3096. doi: 10.21873/anticanres. 14290

Jiang, Y., Zhang, Y., Zhang, L., Wang, M., Zhang, X., and Li, X. (2014). Therapeutic effect of bone marrow mesenchymal stem cells on laser-induced retinal injury in mice. Int. J. Mol. Sci. 15, 9372-9385. doi: 10.3390/ijms15069372

Juan, T., and Fürthauer, M. (2018). Biogenesis and function of ESCRT-dependent extracellular vesicles. Semin. Cell Dev. Biol. 74, 66-77. doi: 10.1016/j.semcdb. 2017.08.022

Kang, M., Choi, J. K., Jittayasothorn, Y., and Egwuagu, C. E. (2020). Interleukin 35-producing exosomes suppress neuroinflammation and autoimmune uveitis. Front. Immunol. 11:1051. doi: 10.3389/fimmu.2020.01051

Kannan, R., Sreekumar, P. G., and Hinton, D. R. (2012). Novel roles for $\alpha$ crystallins in retinal function and disease. Prog. Retinal Eye Res. 31, 576-604. doi: 10.1016/j.preteyeres.2012.06.001

Kannan, R., Sreekumar, P. G., and Hinton, D. R. (2016). Alpha crystallins in the retinal pigment epithelium and implications for the pathogenesis and treatment of age-related macular degeneration. Biochim. Biophys. Acta 1860, 258-268. doi: 10.1016/j.bbagen.2015.05.016

Kase, S., He, S., Sonoda, S., Kitamura, M., Spee, C., Wawrousek, E., et al. (2010). alphaB-crystallin regulation of angiogenesis by modulation of VEGF. Blood 115, 3398-3406. doi: 10.1182/blood-2009-01-197095

Ke, Y., Fan, X., Rui, H., Xinjun, R., Dejia, W., Chuanzhen, Z., et al. (2020). Exosomes derived from RPE cells under oxidative stress mediate inflammation and apoptosis of normal RPE cells through Apaf1/caspase-9 axis. J. Cell. Biochem. 121, 4849-4861.

Kim, Y., Tarallo, V., Kerur, N., Yasuma, T., Gelfand, B. D., Bastos-Carvalho, A., et al. (2014). DICER1/Alu RNA dysmetabolism induces Caspase-8-mediated cell death in age-related macular degeneration. Proc. Natl. Acad. Sci. U.S.A. 111, 16082-16087. doi: 10.1073/pnas.1403814111

Knickelbein, J. E., Liu, B., Arakelyan, A., Zicari, S., Hannes, S., Chen, P., et al. (2016). Modulation of immune responses by extracellular vesicles from retinal pigment epithelium. Invest. Ophthalmol. Vis. Sci. 57, 4101-4107. doi: 10.1167/ iovs.15-18353

Koh, K., Park, M., Bae, E. S., Duong, V. A., Park, J. M., Lee, H., et al. (2020). UBA2 activates $\mathrm{Wnt} / \beta$-catenin signaling pathway during protection of R28 retinal precursor cells from hypoxia by extracellular vesicles derived from placental mesenchymal stem cells. Stem Cell Res. Ther. 11:428.

Kompella, U. B., Hartman, R. R., and Patil, M. A. (2020). Extraocular, periocular, and intraocular routes for sustained drug delivery for glaucoma. Prog. Retinal Eye Res. 100901. doi: 10.1016/j.preteyeres.2020.100901

Koppers-Lalic, D., Hackenberg, M., Bijnsdorp, I. V., van Eijndhoven, M. A. J., Sadek, P., Sie, D., et al. (2014). Nontemplated nucleotide additions distinguish the small RNA composition in cells from exosomes. Cell Rep. 8, 1649-1658. doi: 10.1016/j.celrep.2014.08.027

Kosaka, N., Izumi, H., Sekine, K., and Ochiya, T. (2010). microRNA as a new immune-regulatory agent in breast milk. Silence 1:7. doi: 10.1186/1758-907x$1-7$

Li, D., Zhang, J., Liu, Z., Gong, Y., and Zheng, Z. (2021). Human umbilical cord mesenchymal stem cell-derived exosomal miR-27b attenuates subretinal fibrosis via suppressing epithelial-mesenchymal transition by targeting HOXC6. Stem Cell Res. Ther. 12:24.

Li, Y., Zheng, Q., Bao, C., Li, S., Guo, W., Zhao, J., et al. (2015). Circular RNA is enriched and stable in exosomes: a promising biomarker for cancer diagnosis. Cell Res. 25, 981-984. doi: 10.1038/cr.2015.82 
Liu, C., and Su, C. (2019). Design strategies and application progress of therapeutic exosomes. Theranostics 9, 1015-1028. doi: 10.7150/thno.30853

Liu, C., Ge, H. M., Liu, B. H., Dong, R., Shan, K., Chen, X., et al. (2019). Targeting pericyte-endothelial cell crosstalk by circular RNA-cPWWP2A inhibition aggravates diabetes-induced microvascular dysfunction. Proc. Natl. Acad. Sci. U.S.A. 116, 7455-7464. doi: 10.1073/pnas.1814874116

Liu, W., Yang, D., Chen, L., Liu, Q., Wang, W., Yang, Z., et al. (2020). Plasma exosomal miRNA-139-3p is a novel biomarker of colorectal cancer. J. Cancer 11, 4899-4906. doi: 10.7150/jca.45548

Llorente, A., Skotland, T., Sylvänne, T., Kauhanen, D., Róg, T., Orłowski, A., et al. (2013). Molecular lipidomics of exosomes released by PC-3 prostate cancer cells. Biochim. Biophys. Acta 1831, 1302-1309. doi: 10.1016/j.bbalip.2013. 04.011

Lorizate, M., Sachsenheimer, T., Glass, B., Habermann, A., Gerl, M. J., Kräusslich, H. G., et al. (2013). Comparative lipidomics analysis of HIV-1 particles and their producer cell membrane in different cell lines. Cell. Microbiol. 15, 292-304. doi: $10.1111 / \mathrm{cmi} .12101$

Ma, M., Li, B., Zhang, M., Zhou, L., Yang, F., Ma, F., et al. (2020). Therapeutic effects of mesenchymal stem cell-derived exosomes on retinal detachment. Exp. Eye Res. 191:107899. doi: 10.1016/j.exer.2019.107899

Magayr, T. A., Song, X., Streets, A. J., Vergoz, L., Chang, L., Valluru, M. K., et al. (2020). Global microRNA profiling in human urinary exosomes reveals novel disease biomarkers and cellular pathways for autosomal dominant polycystic kidney disease. Kidney Int. 98, 420-435. doi: 10.1016/j.kint.2020.02.008

Marleau, A. M., Chen, C. S., Joyce, J. A., and Tullis, R. H. (2012). Exosome removal as a therapeutic adjuvant in cancer. J. Transl. Med. 10:134.

Mathew, B., Ravindran, S., Liu, X., Torres, L., Chennakesavalu, M., Huang, C. C., et al. (2019). Mesenchymal stem cell-derived extracellular vesicles and retinal ischemia-reperfusion. J. Biomater. 197, 146-160.

Mead, B., and Tomarev, S. (2017). Bone marrow-derived mesenchymal stem cellsderived exosomes promote survival of retinal ganglion cells through mirnadependent mechanisms. Stem Cells Transl. Med. 6, 1273-1285. doi: 10.1002/ sctm.16-0428

Melo, S. A., Luecke, L. B., Kahlert, C., Fernandez, A. F., Gammon, S. T., Kaye, J., et al. (2015). Glypican-1 identifies cancer exosomes and detects early pancreatic cancer. Nature 523, 177-182. doi: 10.1038/nature14581

Morris, D. R., Bounds, S. E., Liu, H., Ding, W. Q., Chen, Y., Liu, Y., et al. (2020). Exosomal MiRNA transfer between retinal microglia and RPE. Int. J. Mol. Sci. 21:3541. doi: 10.3390/ijms21103541

Nam, G. H., Choi, Y., Kim, G. B., Kim, S., Kim, S. A., and Kim, I. S. (2020). Emerging prospects of exosomes for cancer treatment: from conventional therapy to immunotherapy. Adv. Mater. 32:e2002440.

Nicholson, C., Ishii, M., Annamalai, B., Chandler, K., Chwa, M., Kenney, M. C., et al. (2020a). J or H mtDNA haplogroups in retinal pigment epithelial cells: effects on cell physiology, cargo in extracellular vesicles, and differential uptake of such vesicles by naïve recipient cells. Biochim. Biophys. Acta Gen. Subj. 1865:129798. doi: 10.1016/j.bbagen.2020.129798

Nicholson, C., Shah, N., Ishii, M., Annamalai, B., Brandon, C., Rodgers, J., et al. (2020b). Mechanisms of extracellular vesicle uptake in stressed retinal pigment epithelial cell monolayers. Biochim. Biophys. Acta Mol. Basis Dis. 1866:165608. doi: 10.1016/j.bbadis.2019.165608

Pan, D., Chang, X., Xu, M., Zhang, M., Zhang, S., Wang, Y., et al. (2019). UMSCderived exosomes promote retinal ganglion cells survival in a rat model of optic nerve crush. J. Chem. Neuroanat. 96, 134-139. doi: 10.1016/j.jchemneu.2019. 01.006

Pandey, R. K., and Prajapati, V. K. (2018). Molecular and immunological toxic effects of nanoparticles. Int. J. Biol. Macromol. 107(Pt. A), 1278-1293. doi: 10.1016/j.ijbiomac.2017.09.110

Pascucci, L., Coccè, V., Bonomi, A., Ami, D., Ceccarelli, P., Ciusani, E., et al. (2014). Paclitaxel is incorporated by mesenchymal stromal cells and released in exosomes that inhibit in vitro tumor growth: a new approach for drug delivery. J. Control. Release 192, 262-270. doi: 10.1016/j.jconrel.2014.07.042

Pegtel, D. M., and Gould, S. J. (2019). Exosomes. Annu. Rev. Biochem. 88, 487-514. doi: 10.1016/b978-0-12-816053-4.00021-3

Qu, L., Ding, J., Chen, C., Wu, Z. J., Liu, B., Gao, Y., et al. (2016). ExosomeTransmitted lncARSR promotes sunitinib resistance in renal cancer by acting as a competing endogenous RNA. Cancer Cell 29, 653-668. doi: 10.1016/j.ccell. 2016.03.004
Ragusa, M., Barbagallo, C., Statello, L., Caltabiano, R., Russo, A., Puzzo, L., et al. (2015). miRNA profiling in vitreous humor, vitreal exosomes and serum from uveal melanoma patients: pathological and diagnostic implications. Cancer .Ther. 16, 1387-1396. doi: 10.1080/15384047.2015.1046021

Ricklefs, F. L., Alayo, Q., Krenzlin, H., Mahmoud, A. B., Speranza, M. C., Nakashima, H., et al. (2018). Immune evasion mediated by PD-L1 on glioblastoma-derived extracellular vesicles. Sci. Adv. 4:eaar2766.

Safwat, A., Sabry, D., Ragiae, A., Amer, E., Mahmoud, R. H., and Shamardan, R. M. (2018). Adipose mesenchymal stem cells-derived exosomes attenuate retina degeneration of streptozotocin-induced diabetes in rabbits. J. Circ. Biomark. 7:1849454418807827.

Seyedrazizadeh, S. Z., Poosti, S., Nazari, A., Alikhani, M., Shekari, F., Pakdel, F., et al. (2020). Extracellular vesicles derived from human ES-MSCs protect retinal ganglion cells and preserve retinal function in a rodent model of optic nerve injury. Stem Cell Res. Ther. 11:203.

Shigemoto-Kuroda, T., Oh, J. Y., Kim, D. K., Jeong, H. J., Park, S. Y., Lee, H. J., et al. (2017). MSC-derived extracellular vesicles attenuate immune responses in two autoimmune murine models: type 1 diabetes and uveoretinitis. Stem Cell Rep. 8, 1214-1225. doi: 10.1016/j.stemcr.2017.04.008

Skotland, T., Sandvig, K., and Llorente, A. (2017). Lipids in exosomes: current knowledge and the way forward. Prog. Lipid Res. 66, 30-41. doi: 10.1016/j. plipres.2017.03.001

Tarallo, V., Hirano, Y., Gelfand, B. D., Dridi, S., Kerur, N., Kim, Y., et al. (2012). DICER1 loss and Alu RNA induce age-related macular degeneration via the NLRP3 inflammasome and MyD88. Cell 149, 847-859. doi: 10.1016/j.cell.2012. 03.036

Tassew, N. G., Charish, J., Shabanzadeh, A. P., Luga, V., Harada, H., Farhani, N., et al. (2017). Exosomes mediate mobilization of autocrine Wnt10b to promote axonal regeneration in the injured CNS. Cell Rep. 20, 99-111. doi: 10.1016/j. celrep.2017.06.009

Valadi, H., Ekström, K., Bossios, A., Sjöstrand, M., Lee, J. J., and Lötvall, J. O. (2007). Exosome-mediated transfer of mRNAs and microRNAs is a novel mechanism of genetic exchange between cells. Nat. Cell Biol. 9, 654-659. doi: 10.1038/ncb1596

van Niel, G., D’Angelo, G., and Raposo, G. (2018). Shedding light on the cell biology of extracellular vesicles. Nat. Rev. Mol. Cell Biol. 19, 213-228. doi: 10.1038/nrm.2017.125

Verdera, H. C., Kuranda, K., and Mingozzi, F. (2020). AAV vector immunogenicity in humans: a long journey to successful gene transfer. Mol. Ther. 28, 723-746. doi: 10.1016/j.ymthe.2019.12.010

Villarroya-Beltri, C., Gutiérrez-Vázquez, C., Sánchez-Cabo, F., Pérez-Hernández, D., Vázquez, J., Martin-Cofreces, N., et al. (2013). Sumoylated hnRNPA2B1 controls the sorting of miRNAs into exosomes through binding to specific motifs. Nat. Commun. 4:2980.

Wang, A. L., Lukas, T. J., Yuan, M., Du, N., Tso, M. O., and Neufeld, A. H. (2009). Autophagy, exosomes and drusen formation in age-related macular degeneration. Autophagy 5, 563-564. doi: 10.4161/auto.5.4.8163

Wang, Y., Zhang, Q., Yang, G., Wei, Y., Li, M., Du, E., et al. (2021). RPE-derived exosomes rescue the photoreceptors during retina degeneration: an intraocular approach to deliver exosomes into the subretinal space. Drug Delivery 28, 218-228. doi: 10.1080/10717544.2020.1870584

Wassmer, S. J., Carvalho, L. S., György, B., Vandenberghe, L. H., and Maguire, C. A. (2017). Exosome-associated AAV2 vector mediates robust gene delivery into the murine retina upon intravitreal injection. Sci. Rep. 7:45329.

Wooff, Y., Cioanca, A. V., Chu-Tan, J. A., Aggio-Bruce, R., Schumann, U., and Natoli, R. (2020). Small-Medium extracellular vesicles and their mirna cargo in retinal health and degeneration: mediators of homeostasis, and vehicles for targeted gene therapy. Front. Cell. Neurosci. 14:160. doi: 10.3389/fncel.2020. 00160

Xiao, Y., Zhong, J., Zhong, B., Huang, J., Jiang, L., Jiang, Y., et al. (2020). Exosomes as potential sources of biomarkers in colorectal cancer. Cancer Lett. 476, 13-22. doi: 10.1016/j.canlet.2020.01.033

Xu, C. G., Yang, M. F., Ren, Y. Q., Wu, C. H., and Wang, L. Q. (2016). Exosomes mediated transfer of IncRNA UCA1 results in increased tamoxifen resistance in breast cancer cells. Eur. Rev. Med. Pharm. Sci. 20, 4362-4368.

Xu, R., Rai, A., Chen, M., Suwakulsiri, W., Greening, D. W., and Simpson, R. J. (2018). Extracellular vesicles in cancer - implications for future improvements in cancer care. Nat. Rev. Clin. Oncol. 15, 617-638. doi: 10.1038/s41571-0180036-9 
Xu, Z., Li, P., Fan, L., and Wu, M. (2018). The potential role of circRNin, A., tumor immunity regulation and immunotherapy. Front. Immunol. 9:9. doi: 10.3389/fimmu.2018.00009

Yan, B., Gao, L., Huang, Y., Wang, X., Lang, X., Yan, F., et al. (2020). Exosomes derived from BDNF-expressing $293 \mathrm{~T}$ attenuate ischemic retinal injury in vitro and in vivo. Aging 12. doi: 10.18632/aging.202245

Yang, C., Shani, S., Tahiri, H., Ortiz, C., Gu, M., Lavoie, J. C., et al. (2020). Extracellular microparticles exacerbate oxidative damage to retinal pigment epithelial cells. Exp. Cell Res. 390:111957. doi: 10.1016/j.yexcr.2020.11 1957

Yu, B., Shao, H., Su, C., Jiang, Y., Chen, X., Bai, L., et al. (2016). Exosomes derived from MSCs ameliorate retinal laser injury partially by inhibition of MCP-1. Sci. Rep. 6:34562.

Zeng, Y., Yao, X., Liu, X., He, X., Li, L., Liu, X., et al. (2019). Antiangiogenesis triggers exosomes release from endothelial cells to promote tumor vasculogenesis. J. Extracell. Vesicles 8:1629865. doi: 10.1080/20013078.2019. 1629865

Zhang, W., Dong, X., Wang, T., and Kong, Y. (2019a). Exosomes derived from platelet-rich plasma mediate hyperglycemia-induced retinal endothelial injury via targeting the TLR4 signaling pathway. Exp. Eye Res. 189:107813. doi: 10. 1016/j.exer.2019.107813

Zhang, W., Jiang, H., and Kong, Y. (2020). Exosomes derived from platelet-rich plasma activate YAP and promote the fibrogenic activity of Müller cells via the PI3K/Akt pathway. Exp. Eye Res. 193:107973. doi: 10.1016/j.exer.2020. 107973

Zhang, W., Ma, Y., Zhang, Y., Yang, J., He, G., and Chen, S. (2019b). PhotoOxidative blue-light stimulation in retinal pigment epithelium cells promotes exosome secretion and increases the activity of the NLRP3 inflammasome. Curr. Eye Res. 44, 67-75. doi: 10.1080/02713683.2018.1518458
Zhang, W., Wang, Y., and Kong, Y. (2019c). Exosomes derived from mesenchymal stem cells modulate miR-126 to ameliorate hyperglycemia-induced retinal inflammation via targeting HMGB1. Invest. Ophthalmol. Vis. Sci. 60, 294-303. doi: $10.1167 /$ iovs.18-25617

Zhang, X., Liu, J., Yu, B., Ma, F., Ren, X., and Li, X. (2018). Effects of mesenchymal stem cells and their exosomes on the healing of large and refractory macular holes. Graefes Arch. Clin. Exp. Ophthalmol. 256, 2041-2052. doi: 10.1007/ s00417-018-4097-3

Zhang, Y., Wang, K., Pan, J., Yang, S., Yao, H., Li, M., et al. (2020). Exosomes mediate an epithelial-mesenchymal transition cascade in retinal pigment epithelial cells: implications for proliferative vitreoretinopathy. J. Cell. Mol. Med. 24, 13324-13335. doi: 10.1111/jcmm.15951

Zheng, H., Yang, F., Ea, V., Zhou, L., Wu, L., Zhao, G., et al. (2020). Proteomics profiling of plasma exosomes in VKH patients. Curr. Mol. Med. doi: 10.2174/ 1566524020666200719021653

Zhu, L., Zang, J., Liu, B., Yu, G., Hao, L., Liu, L., et al. (2020). Oxidative stressinduced RAC autophagy can improve the HUVEC functions by releasing exosomes. J. Cell. Physiol. 235, 7392-7409. doi: 10.1002/jcp.29641

Conflict of Interest: The authors declare that the research was conducted in the absence of any commercial or financial relationships that could be construed as a potential conflict of interest.

Copyright (c) 2021 Zhang, Mugisha, Fransisca, Liu, Xie and Hu. This is an open-access article distributed under the terms of the Creative Commons Attribution License (CC BY). The use, distribution or reproduction in other forums is permitted, provided the original author(s) and the copyright owner(s) are credited and that the original publication in this journal is cited, in accordance with accepted academic practice. No use, distribution or reproduction is permitted which does not comply with these terms. 